\title{
Thyroid hormone stimulation of osteocalcin gene expression in ROS $17 / 2 \cdot 8$ cells is mediated by transcriptional and post-transcriptional mechanisms
}

\author{
C H Gouveia ${ }^{1,2}$, J J Schultz ${ }^{1}$, A C Bianco ${ }^{2,3}$ and G A Brent ${ }^{1}$ \\ ${ }^{1}$ Molecular Endocrinology Laboratory, VA Greater Los Angeles Healthcare System and Departments of Medicine and Physiology, UCLA School of Medicine, \\ Los Angeles, California, USA \\ ${ }^{2}$ Department of Physiology, University of São Paulo, São Paulo, Brazil \\ ${ }^{3}$ Thyroid Division, Brigham and Women's Hospital, Harvard Medical School, Boston, Massachusetts, USA \\ (Requests for offprints should be addressed to G A Brent, Molecular Endocrinology Laboratory, Bldg 114, Room 230, VA Greater Los Angeles Healthcare \\ System, 11301 Wilshire Blvd, Los Angeles, California 90073, USA; Email: gbrent@ucla.edu)
}

\begin{abstract}
We investigated the mechanism of thyroid hormone regulation of osteocalcin (OC) gene expression in osteoblast-like cells (ROS 17/2.8). Treatment with triiodothyronine $\left(\mathrm{T}_{3}\right)\left(10^{-8} \mathrm{M}\right)$ increased OC mRNA levels by $\sim 3$-fold after $24 \mathrm{~h}$ and reached a maximum, $\sim 5 \cdot 4$-fold, after $48 \mathrm{~h}$. The mRNA levels of other bonespecific genes, alkaline phosphatase and osteopontin, were not affected by $\mathrm{T}_{3}$ treatment. Interestingly, $\mathrm{T}_{3}$ induction of OC mRNA varied according to cell density: $\sim 4$-fold at $\sim 1 \times 10^{5}$ cells $/$ dish and $1 \cdot 5$-fold at $40-60 \times 10^{5}$ cells/ dish. The magnitude of OC mRNA induction by $\mathrm{T}_{3}$ was $\sim 40 \%$ lower than induction by 1,25 dihydroxyvitamin $\mathrm{D}_{3}$ $\left(1,25 \mathrm{D}_{3}\right)$ alone, and the combination of $\mathrm{T}_{3}+1,25 \mathrm{D}_{3}$ did not further stimulate $\mathrm{OC}$ mRNA levels. $\mathrm{T}_{3}$ induction of OC mRNA was not affected by treatment with cycloheximide $(10 \mu \mathrm{g} / \mathrm{ml})$ for $5 \mathrm{~h}$ indicating that new protein synthesis is not required for the response. To study the half-life of OC mRNA, ROS $17 / 2 \cdot 8$ cells were incubated
\end{abstract}

with actinomycin D. The basal half-life of OC mRNA (means \pm s.E.M.) was $6 \cdot 4 \pm 0 \cdot 2 \mathrm{~h}$ which was increased significantly with either $\mathrm{T}_{3}$ or $1,25 \mathrm{D}_{3}$ treatment to $10.9 \pm 0.6 \mathrm{~h}$ and $13.5 \pm 0.4 \mathrm{~h}$ respectively. $\mathrm{T}_{3}$ modestly up-regulated the rate of OC gene transcription $(1 \cdot 7 \pm 0 \cdot 2-$ fold) as determined by run-off assay. $\mathrm{T}_{3}$ did not induce a reporter construct containing the rat $\mathrm{OC}$ gene (rOC) $5^{\prime}$-flanking region (to $-1750 \mathrm{bp}$ ) or the previously described rOC vitamin $\mathrm{D}$ response element, when transfected into ROS $17 / 2 \cdot 8$ cells. In conclusion, $T_{3}$ up-regulates the OC mRNA expression in ROS 17/2.8 cells in a dose-, time- and cell confluence-dependent fashion, and does so by transcriptional and posttranscriptional mechanisms. The greater $\mathrm{T}_{3}$ induction of OC expression in ROS $17 / 2 \cdot 8$ cells at low cell density is consistent with findings of thyroid hormone action on bone development.

Journal of Endocrinology (2001) 170, 667-675

\section{Introduction}

Thyroid hormone is essential for normal skeletal development, maturation and metabolism. Hypothyroidism impairs skeletal maturation and leads to epiphyseal dysgenesis, resulting in growth retardation and skeletal abnormalities (Allain \& McGregor 1993). In adults, thyrotoxicosis is frequently associated with increased bone turnover and decreased bone mass, which is the result of excessive bone resorption relative to formation (Mosekilde \& Melsen 1978, Krolner et al. 1983).

Thyroid receptors (TRs) have been demonstrated in rat, mouse and human osteoblasts (Rizzoli et al. 1986, Sato et al. 1987, LeBron et al. 1989, Allain et al. 1996). TR $\alpha$ and $\beta$ isoforms are present, in varying proportions, in three osteosarcoma cell lines with phenotypes of fibroblast, preosteoblast and osteoblast like (ROS 25/1, UMR 1 O6 and ROS $17 / 2 \cdot 8$ respectively) (Williams et al. 1994). In addition, the expression of TR $\beta_{1}$ is modulated during osteoblast-like cell differentiation, suggesting an important role in bone development. TR $\alpha 1 / \alpha 2$ and $\operatorname{TR} \alpha / \beta$ combined knockout mice have a number of bone defects including: delayed bone maturation, impaired bone mineralization and delayed ossification of epiphysis and diaphysis (Fraichard et al. 1997, Gauthier et al. 1999, Göthe et al. 1999).

Despite the multiple in vivo effects of thyroid hormone on bone, only a few genes directly regulated by tri-iodothyronine $\left(T_{3}\right)$ have been identified. In MC3T3 murine osteoblast cells, the collagenase-3 and gelatinase $\mathrm{B}$ genes are up-regulated by $\mathrm{T}_{3}$ and may mediate increased collagen degradation in cultured intact rat calvariae (Pereira et al. 1999). For both of these genes, $\mathrm{T}_{3}$-induced mRNA accumulation is mediated by 
transcriptional mechanisms, and mRNA half-life is not influenced by $\mathrm{T}_{3}$.

A key osteoblast protein shown to be regulated by thyroid hormone is osteocalcin (OC), or bone gla protein, a small protein that contains 45-60 amino acid residues. It is the major non-collagenous protein $(10 \%)$ of the bone extracellular matrix and is synthesized almost exclusively by mature osteoblasts during the late stages of differentiation and during the onset of matrix mineralization (Aronow et al. 1990). The function of OC is not completely understood; however, it is believed to play a role in bone formation and remodeling. OC knockout mice have increased bone density, suggesting that $\mathrm{OC}$ is an inhibitor of bone formation and that it may be required for bone mineral maturation (Ducy et al. 1996, Boskey et al. 1998). OC has also been shown to play a role in bone resorption (Glowacki \& Lian 1987, McSheehy \& Chambers 1987).

The close correlation of the serum concentration of OC and thyroid status has been shown in a number of clinical studies (Yoneda et al. 1988, Kojima et al. 1992, Lerger et al. 1997). In hyperthyroid patients, there is a linear correlation between serum levels of OC and either free thyroxine $\left(T_{4}\right)$ or free $T_{3}$. Hypothyroid patients have reduced levels of serum $\mathrm{OC}$, which are rapidly normalized after $\mathrm{T}_{4}$ treatment. Rats treated with excessive levels of thyroid hormone have a dose-dependent increase in the levels of OC mRNA in the femur (Ross \& Graichen 1991, Kung \& Ng 1994). In situ hybridization experiments document that $\mathrm{T}_{4}$ treatment increases expression of $\mathrm{OC}$ mRNA in femoral osteoblasts, but not in vertebral osteoblasts (Kung \& Ng 1994), pointing towards a differential response of vertebral and femoral osteoblasts to thyroid hormone. Rats treated with high dose $\mathrm{T}_{4}$ for 28 days have reduced bone mineral density in the femur but not in the spine, corresponding to the regions of thyroid hormoneinduced OC mRNA expression (Gouveia et al. 1997). This is also in agreement with clinical findings of reduced femoral rather than vertebral bone mineral density in thyrotoxicosis (Diamond et al. 1991).

Despite all of the clinical and experimental data showing a correlation between $\mathrm{OC}$ and $\mathrm{T}_{3}$ levels, the mechanism of OC regulation by $\mathrm{T}_{3}$ in osteoblasts is not well understood. We investigated these mechanisms in ROS $17 / 2 \cdot 8$ cells, a rat osteosarcoma cell line that expresses an osteoblast-like phenotype. $\mathrm{T}_{3}$ increases OC mRNA levels by both transcriptional and post-transcriptional mechanisms.

\section{Materials and Methods}

\section{Cell culture}

The rat osteosarcoma cell lines ROS 17/2.8 were grown in complete media (CM; Ham's F-12 medium (GibcoBRL, Grand Island, NY, USA) supplemented with 5\% (v:v) fetal bovine serum (FBS; Gibco-BRL)), in a humidity controlled incubator, at $37{ }^{\circ} \mathrm{C}$ and $5 \% \mathrm{CO}_{2}$. The $\mathrm{pH}$ of the media was kept between $7 \cdot 2$ and $7 \cdot 6$. Stock solutions of $\mathrm{T}_{3}\left(10^{-4} \mathrm{M}\right.$ in $\left.0.02 \mathrm{NaOH}\right)$, all-trans retinoic acid (RA; $10^{-4} \mathrm{M}$ in methanol), 9-cis-RA retinoic acid (9cis-RA; $10^{-4} \mathrm{M}$ in ethanol) and 1,25 dihydroxyvitamin $\mathrm{D}_{3}\left(1,25 \mathrm{D}_{3} ; 10^{-5} \mathrm{M}\right.$ in isopropanol) (all from Sigma Chemical Co., St Louis, MO, USA), were diluted in serum-free media (SF; Ham's F-12 medium supplemented with insulin $(5 \mu \mathrm{g} / \mathrm{ml})$, transferrin $(5 \mu \mathrm{g} / \mathrm{ml})$ and $\mathrm{Na}_{2} \mathrm{SeO}_{3}$ $(5 \mathrm{ng} / \mathrm{ml})$ (Sigma Chemical Co.)) as previously described (Williams et al. 1994). Cells were grown in SF media for $24 \mathrm{~h}$ prior to hormone treatment studies.

\section{Dose-response, time-response and cell-density studies}

Cells were plated in a density of $10^{6}$ cells $/ 100 \mathrm{~mm}$ culture dishes (Falcon; Becton Dickinson, NJ, USA) and allowed to grow for $72 \mathrm{~h}$ in $12 \mathrm{ml} \mathrm{CM}$. Cells were washed twice with Dulbecco's phosphate-buffered saline (PBS) (Gibco$\mathrm{BRL}$ ) and incubated for $24 \mathrm{~h}$ in $12 \mathrm{ml} \mathrm{SF}$ media. For the dose-response studies, cells were treated with $\mathrm{T}_{3}\left(10^{-11}\right.$ to $\left.10^{-8} \mathrm{M}\right)$, RA $\left(10^{-11}\right.$ to $\left.10^{-6} \mathrm{M}\right)$, 9-cis-RA $\left(10^{-11}\right.$ to $\left.10^{-6} \mathrm{M}\right)$ or $1,25 \mathrm{D}_{3}\left(10^{-11}\right.$ to $\left.10^{-8} \mathrm{M}\right)$ for $24 \mathrm{~h}$. For the time-response studies, cells were treated with $\mathrm{T}_{3}$ $\left(10^{-8} \mathrm{M}\right)$ for varying periods of time $(6,18,24,48$ and $72 \mathrm{~h}$ ) and the cell culture media were changed every $24 \mathrm{~h}$. For the cell-density studies, cells were plated in varying densities $\left(10^{5}, 2 \times 10^{5}, 4 \times 10^{5}, 6 \times 10^{5}, 8 \times 10^{5}, 10^{6}\right.$, $2 \times 10^{6}, 4 \times 10^{6}$ and $6 \times 10^{6}$ cells/dish). Cells were also kept in SF media for $24 \mathrm{~h}$ and prior to $\mathrm{T}_{3}$ treatment $\left(10^{-8} \mathrm{M}\right)$ for $24 \mathrm{~h}$.

\section{Effect of protein inhibitor on OC $m R N A$ synthesis}

A total of $10^{6}$ cells were plated in $100 \mathrm{~mm}$ dishes, grown in CM for $72 \mathrm{~h}$, washed twice with Dulbecco's PBS and maintained in SF media for $24 \mathrm{~h}$. They were next exposed to $10 \mu \mathrm{g} / \mathrm{ml}$ cycloheximide (CHX; Sigma Chemical Co.) for 5,10 or $18 \mathrm{~h}$ while being treated with $\mathrm{T}_{3}\left(10^{-8} \mathrm{M}\right)$, $1,25 \mathrm{D}_{3}\left(10^{-8} \mathrm{M}\right)$ or $\mathrm{T}_{3}+1,25 \mathrm{D}_{3}$ for $24 \mathrm{~h}$. After $\mathrm{CHX}$ treatment, cells were again washed twice with PBS and returned to the hormone-supplemented SF media until completing $24 \mathrm{~h}$ of hormone treatment. Total RNA was then extracted for Northern blot analysis.

\section{Determination of OC $m R N A$ half-life}

Cells were plated as described above and kept in SF media for $24 \mathrm{~h}$ before being treated with $\mathrm{T}_{3}\left(10^{-8} \mathrm{M}\right), 1,25 \mathrm{D}_{3}$ $\left(10^{-8} \mathrm{M}\right)$ or both hormones for $24 \mathrm{~h}$. After hormone treatment, cells were washed twice with Dulbecco's PBS and transferred to SF media with actinomycin D (AD; $5 \mu \mathrm{g} / \mathrm{ml}$; Sigma Chemical Co.). Cells were harvested every $3 \mathrm{~h}$ for a total of $9 \mathrm{~h}$. Total RNA was isolated and analyzed by Northern blot. The percentage of remaining mRNA was calculated by comparing the amount of OC mRNA at each time-point to the amount of OC 
mRNA present at the time-point zero of $\mathrm{AD}$ treatment, after normalization to glyceraldehyde-3-phosphatedehydrogenase (GAPDH) mRNA or 18 S ribosomal RNA expression.

\section{RNA isolation and Northern blot analysis}

Total RNA was extracted from cultured cells using TRizol (Gibco-BRL), according to the manufacturer's instructions. Northern blots were performed as previously described (Ausubel et al. 1997). Briefly, electrophoresis of $30-40 \mu \mathrm{g}$ RNA per lane was performed in a $2 \cdot 2 \%$ agarose-formaldehyde gel. The RNA was transferred in $20 \times \operatorname{SSPE}\left(3 \mathrm{M} \mathrm{NaCl}, 0 \cdot 2 \mathrm{M} \mathrm{NaH}_{2} \mathrm{PO}_{4} \mathrm{H}_{2} \mathrm{O}, 0.02 \mathrm{M}\right.$ EDTA, pH 7.4) from the gel to a nylon membrane (Gene Screen Plus; DuPont, Boston, MA, USA), which was prehybridized for $4 \mathrm{~h}$ and hybridized for $24 \mathrm{~h}$ at $42{ }^{\circ} \mathrm{C}$ in a hybridization oven (Bellco Glass Inc., Vineland, NJ, USA). Approximately $1 \cdot 2 \mathrm{ng}$ purified ${ }^{32} \mathrm{P}$-labeled cDNA probes for alkaline phosphatase (ALP), OC, osteopontin (OP), GAPDH (gifts from Dr Akiko Ida-Klein, VA Medical Center, Los Angeles, CA, USA), $\beta$-actin or $18 \mathrm{~S}$ rRNA (Ambion, Austin, TX, USA) were added per ml hybridization solution. The specific activity of the probes was approximately $1.7 \times 10^{-9}$ c.p.m. $/ \mu \mathrm{g}$ cDNA. Hybridized filters were then washed once with $2 \times$ SSPE for $15 \mathrm{~min}$ at room temperature, once with $2 \times$ SSPE with $2 \% \operatorname{SDS}$ for $45 \mathrm{~min}$ at $65^{\circ} \mathrm{C}$, and once with $0 \cdot 1 \times \mathrm{SSPE}$ for $15 \mathrm{~min}$ at room temperature. Membranes were then exposed to film for $24 \mathrm{~h}$ or less to phosphorimager screens. Hybridization signal intensity was measured by densitometry of autoradiograms using the NIH image software (Scientific Computing Resource Center, National Institutes of Health, Bethesda, MD, USA) or by PhosphorImager analysis of the radioactive signal captured by phosphor screens (Molecular Dynamics, Sunnyvale, CA, USA).

\section{Nuclear run-off transcription analysis}

Nuclei of control and $\mathrm{T}_{3}$-treated $\left(10^{-8} \mathrm{M}\right.$ for $\left.24 \mathrm{~h}\right) \mathrm{ROS}$ $17 / 2 \cdot 8$ cells were prepared as previously described (Ausubel et al. 1997) with modifications (Mosavin \& Mellon 1996). Transcription assays were performed on $200 \mu \mathrm{l}$ frozen nuclei from SF- and $\mathrm{T}_{3}$-treated cells thawed at room temperature and transferred to two $15 \mathrm{ml}$ conical polypropylene centrifuge tubes. The radiolabeled RNAs were extracted using TRizol (Gibco-BRL) and the SF and $\mathrm{T}_{3}$ RNA samples were normalized for c.p.m. prior to hybridization. The labeled RNA probes were hybridized to slot blot membranes containing $20 \mu \mathrm{g} \mathrm{NaOH}$ denatured OC and GAPDH cDNAs, which were isolated by enzymatic digestion from their vectors, pGEM-4Z and pBluescript respectively. The prehybridization and hybridization were performed as described for Northern blot; however, hybridization was performed for $72 \mathrm{~h}$. The GAPDH signal was used for normalization.
Chloramphenicol acetyltransferase and luciferase fusion genes

For experiments using the OC promoter, the plasmid POC $_{2 \cdot 0}$ CAT (a gift from Dr Marie B Demay, Massachusetts General Hospital, Boston, MA, USA), which contains the rOC promoter sequence from -1750 to -8 fused to the chloramphenicol acetyltransferase (CAT) gene (Demay et al. 1989), was employed. A 53 bp oligonucleotide containing the rat $\mathrm{OC} 1,25 \mathrm{D}_{3}$ responsive element (VDRE) and a critical sequence for $1,25 \mathrm{D}_{3}$ transactivation (Sneddon et al. 1997) was synthesized (Life Technologies, Grand Island, NY, USA) and inserted into the BglII site of pGL3 basic vector (Promega, Madison, WI, USA), which contains luciferase (LUC) as gene reporter, to yield rOCVDRE-LUC. This region is identical to the OC promoter sequence, -458 to -410 , previously reported (Sneddon et al. 1997). Orientation and copy number of the oligonucleotide in each construct were determined by digestion and confirmed by DNA sequencing.

\section{Transfections}

ROS $17 / 2 \cdot 8$ cells maintained in CM were reseeded $\left(10^{5}\right.$ cells/well of 12 -well plates) $24 \mathrm{~h}$ before transfection and kept, until harvesting, in Ham's F-12 medium supplemented with 5\% charcoal-stripped FBS and $1 \times$ penicillin-streptomycin-glutamin (Life Technologies). Transfections were carried out by Effectene Transfection Reagent (Qiagen, Valencia, CA, USA), a non-liposomal lipid-based reagent, with $0 \cdot 2 \mu \mathrm{g}$ test plasmid and $0 \cdot 1 \mu \mathrm{g}$ control plasmid/well. After $18 \mathrm{~h}$ of cell incubation with transfection complexes, the cells were washed with Dulbecco's PBS, $1 \mathrm{ml}$ fresh media plus hormone $\left(\mathrm{T}_{3}, 1,25 \mathrm{D}_{3}\right.$ or $\mathrm{T}_{3}+1,25 \mathrm{D}_{3}$, all at $\left.10^{-8} \mathrm{M}\right)$ was added and again after $24 \mathrm{~h}$ of hormone treatment. Following $48 \mathrm{~h}$ of hormone treatment, cells were harvested and cell lysates prepared using $120 \mu$ Reporter Lysis Buffer (Promega) per well. All test plasmids were co-transfected with a control plasmid, pxGH5, which expresses human growth hormone (hGH). The hGH secreted by transfected cells to the medium was assayed by hGHTGES 100T Kit (Nichols Institute Diagnostics, San Juan Capistrano, CA, USA). CAT activity was assessed by liquid scintillation counter as described in the protocol of the CAT Enzyme Assay System (Promega). LUC activity was measured using the Luciferase Assay System (Promega) and the TD-20/20 Luminometer (Promega). Each sample was assayed in duplicate and normalized by hGH, yielding relative CAT or LUC activities (CAT or LUC activity counts/hGH counts).

\section{Statistical analysis}

The expression of mRNA and CAT is shown as means \pm S.E.M. Densitometric values were normalized by 
the expression of GAPDH or $\beta$-actin (18S rRNA for cell density studies) and expressed as arbitrary units (density of tested mRNA/density of control). For all experiments, fold-induction is relative to the control values, which were considered to be 1 . One-way analysis of variance (ANOVA) was used to compare more than two groups and was followed by the Student-Newman-Keuls test in order to detect differences between groups. The Student's $t$-test (unpaired) was used to analyze the effect of $\mathrm{T}_{3}$ at the transcriptional level (run-off assay). To calculate the mRNA half-life, OC mRNA decay was analyzed by linear regression of the percent RNA remaining at each time-point of $\mathrm{AD}$ treatment. For all tests, $P \leqslant 0.05$ was considered statistically significant. GraphPad Instat was used for statistical analysis and Prism software for linear regressions (GraphPad Software Inc., San Diego, CA, USA).

\section{Results}

$\mathrm{T}_{3}$ stimulated OC mRNA levels in a dose-dependent fashion (Fig. 1). $\mathrm{T}_{3}$ induction of $2 \cdot 4$ - to $3 \cdot 0$-fold $(P<0 \cdot 05)$ was seen at $24 \mathrm{~h}$ with $\mathrm{T}_{3}$ concentrations of $10^{-9}$ and $10^{-8} \mathrm{M}$ respectively. The expression of two other bonespecific genes, ALP and OP, were not modulated by $\mathrm{T}_{3}$ treatment at any hormone concentration. $\mathrm{T}_{3}\left(10^{-8} \mathrm{M}\right)$ stimulated OC mRNA expression in a time-dependent manner (Fig. 2). Significant induction of OC mRNA, approximately $2 \cdot 5$-fold $(P<0.02)$, was detected at $24 \mathrm{~h}$. The maximum effect, approximately $5 \cdot 4$-fold $(P<0 \cdot 001)$, was reached after $48 \mathrm{~h}$ of $\mathrm{T}_{3}$ exposure and remained constant after $72 \mathrm{~h}$ of $\mathrm{T}_{3}$ treatment. The broad OC mRNA band is typically observed in Northern blots, due to variability in the length of the poly(A) tail of the OC transcript (observed range of 580-660 nucleotides) (Pan \& Price 1985).

A factor that may have led to variability of $\mathrm{T}_{3}$ responsiveness of OC in previous studies is the extent of cell to cell contact. Previous studies have shown that an increase in $\operatorname{ROS} 17 / 2 \cdot 8$ cell density inhibits expression of proliferation-specific genes (e.g. histone $\mathrm{H} 4$ and $\mathrm{H} 2 \mathrm{~B}$ genes) and increases expression of bone-related genes, including OC (van den Ent et al. 1993). We tested the effect of cell density on the $\mathrm{T}_{3}$ induction of $\mathrm{OC}$ mRNA. Increased basal expression of OC mRNA was seen with increased cell density, while the magnitude of $\mathrm{T}_{3}$ induction decreased (Fig. 3). Among the control cells ( - ), the OC mRNA expression was 5- and 9.8-fold higher $(P<0 \cdot 001)$ in cells that were plated at $40 \times 10^{5}$ and $60 \times 10^{5}$ cells/dish respectively, when compared with cells that were plated at $10^{5}$ cells/dish (Fig. 3B). At lower cell densities, however, $\mathrm{T}_{3}$ significantly induced $\mathrm{OC}$ mRNA expression (Fig. $3 \mathrm{~B}$ and $\mathrm{C}$ ). In cells that were initially plated at $10^{5}$ and $4 \times 10^{5}$ cells/dish (approximately $10-30 \%$ confluent at the end of the experiment),
(A)

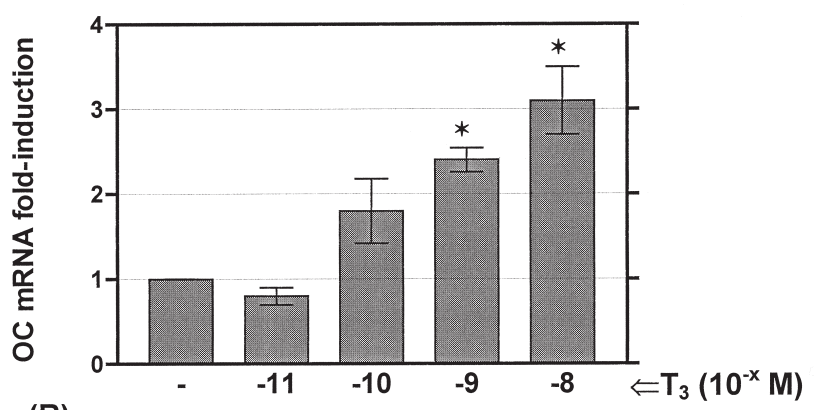

(B)

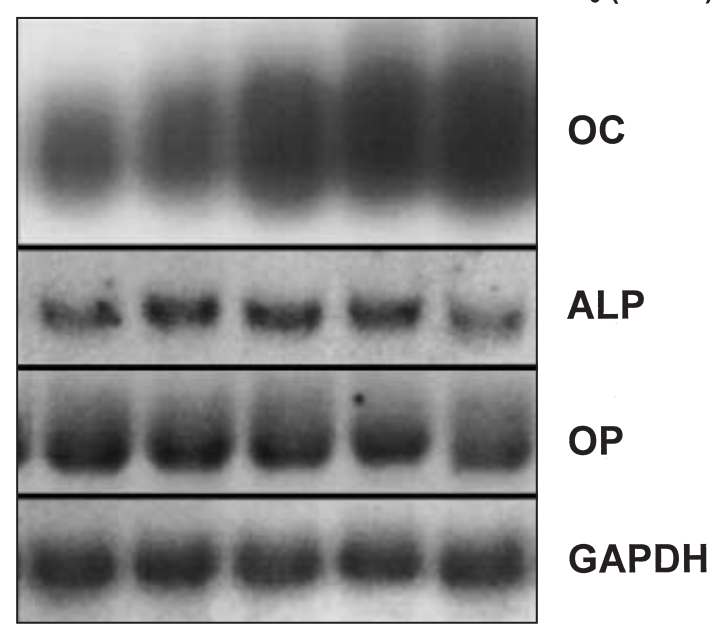

Figure 1 Expression of OC, ALP and OP mRNA in ROS 17/2.8 cells. SF-cultured cells were treated with $\mathrm{T}_{3}\left(10^{-11}\right.$ to $\left.10^{-8} \mathrm{M}\right)$ for $24 \mathrm{~h}$. (A) Densitometric analysis shows the $T_{3}$-induced changes in OC mRNA expression normalized to GAPDH mRNA. Data are given as fold-induction relative to the control $(-)$. Values are means \pm S.E.M. $(n=3)$. ${ }^{*} P<0 \cdot 05$ vs control $(-)$. (B) Northern blot of $30 \mu \mathrm{g}$ total RNA/lane hybridized with OC, OP, ALP and GAPDH ${ }^{32}$ P-labeled cDNA probes.

$\mathrm{T}_{3}$ induced OC mRNA by approximately 4 -fold. This $\mathrm{T}_{3}$-mediated induction was progressively and significantly reduced as cell density was increased (Fig. 3B and C), falling to $1 \cdot 5$-fold induction in cells that were plated at $6 \times 10^{6} \mathrm{cells} /$ dish (overly confluent cells).

Since it is known that TRs may form heterodimers with retinoic acid receptors (RAR), retinoid $\mathrm{x}$ receptors (RXR) or vitamin D nuclear receptors (VDR), we next determined if the combination of $\mathrm{T}_{3}$ with RA, 9-cis-RA or $1,25 \mathrm{D}_{3}$ would influence the effect of $\mathrm{T}_{3}$ treatment on OC mRNA expression (data not shown). Treatment with $\mathrm{T}_{3}$ alone resulted in $\sim 3$-fold induction of OC mRNA expression $(P<0 \cdot 05$ vs SF). RA and 9-cis-RA alone induced the OC mRNA approximately 2-fold (not a statistically significant increase), but did not further stimulate the $\mathrm{T}_{3}$-induced expression of $\mathrm{OC}$ mRNA. $1,25 \mathrm{D}_{3}$ stimulated $\mathrm{OC}$ mRNA expression at a higher magnitude than $\mathrm{T}_{3}(5 \cdot 1$-fold vs $3 \cdot 0$-fold, $P<0 \cdot 05)$ and the 


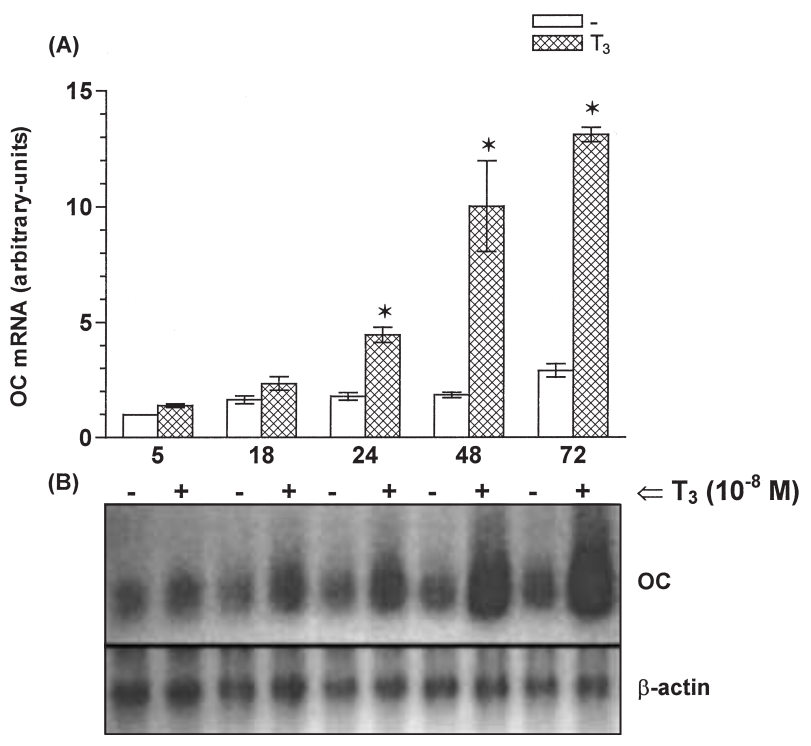

Figure 2 Time-course of OC mRNA expression in ROS 17/2.8 cells. SF-cultured cells were treated with $10^{-8} \mathrm{M} \mathrm{T}_{3}$ for 5, 18, 24 and $72 \mathrm{~h}$. (A) Densitometric analysis shows the $\mathrm{T}_{3}$-induced changes in OC mRNA expression. Data are given in arbitrary density units $(\mathrm{OC} / \beta$-actin $)$ and as means \pm S.E.M. $(n=3)$. $P$ value by ANOVA is $<0.0001 ;{ }^{*} P<0.05$ vs control $(-)$ of each time-point. (B) Northern blot of $30 \mu \mathrm{g}$ total RNA/lane hybridized with OC and $\beta$-actin ${ }^{32}$ P-labeled cDNA probes. $\beta$-actin mRNA expression was used for normalization.

combination of $\mathrm{T}_{3}$ and $1,25 \mathrm{D}_{3}$ treatments did not further stimulate the OC mRNA expression greater than $1,25 \mathrm{D}_{3}$ alone $(6 \cdot 2$-fold vs $5 \cdot 1$-fold, $P>0 \cdot 05)$.

CHX treatment was used to determine if de novo protein synthesis was required for $\mathrm{T}_{3}$ stimulation of $\mathrm{OC}$ expression. Since $1,25 \mathrm{D}_{3}$ is known to directly regulate OC gene transcription via the VDR, we also compared $\mathrm{T}_{3}, 1,25 \mathrm{D}_{3}$ and $\mathrm{T}_{3}+1,25 \mathrm{D}_{3}$ treatments in the presence of CHX. The induction of OC mRNA expression by $\mathrm{T}_{3}$ was unaffected by $5 \mathrm{~h}$ of $\mathrm{CHX}$ treatment, while the $1,25 \mathrm{D}_{3}-$ and the $1,25 \mathrm{D}_{3}+\mathrm{T}_{3}$-mediated induction was increased, reaching $\sim 13$-fold $(P<0 \cdot 001)$ (Fig. 4$)$. It is noteworthy that, after $10 \mathrm{~h}$ of $\mathrm{CHX}, \mathrm{T}_{3}$ did not significantly induce OC expression, while $1,25 \mathrm{D}_{3}$ was still able to up-regulate OC mRNA (8.6-fold, $P<0 \cdot 001)$. After $18 \mathrm{~h}$ of CHX, neither $\mathrm{T}_{3}$ nor $1,25 \mathrm{D}_{3}$ stimulated $\mathrm{OC}$ expression.

To analyze if $\mathrm{T}_{3}$ up-regulation of OC mRNA was due to a post-transcriptional effect, we assessed whether $\mathrm{T}_{3}$ treatment modified OC mRNA stability. In addition, we also compared the effects of $\mathrm{T}_{3}$ with those of $1,25 \mathrm{D}_{3}$ alone and in combination with $\mathrm{T}_{3}$ (Table 1). The baseline half-life of OC mRNA was $\sim 6 \cdot 4 \pm 0 \cdot 2 \mathrm{~h}$. $\mathrm{T}_{3}$ treatment stabilized the OC mRNA, increasing the mRNA half-life to $10 \cdot 9 \pm 0 \cdot 6 \mathrm{~h} .1,25 \mathrm{D}_{3}$ treatment prolonged OC mRNA half-life to $13 \cdot 5 \pm 0 \cdot 4 \mathrm{~h}$. The combination of $\mathrm{T}_{3}$ with $1,25 \mathrm{D}_{3}$ treatment resulted in an OC mRNA half-life of $11 \cdot 9 \pm 1 \cdot 3 \mathrm{~h}$.
(A)

(B)
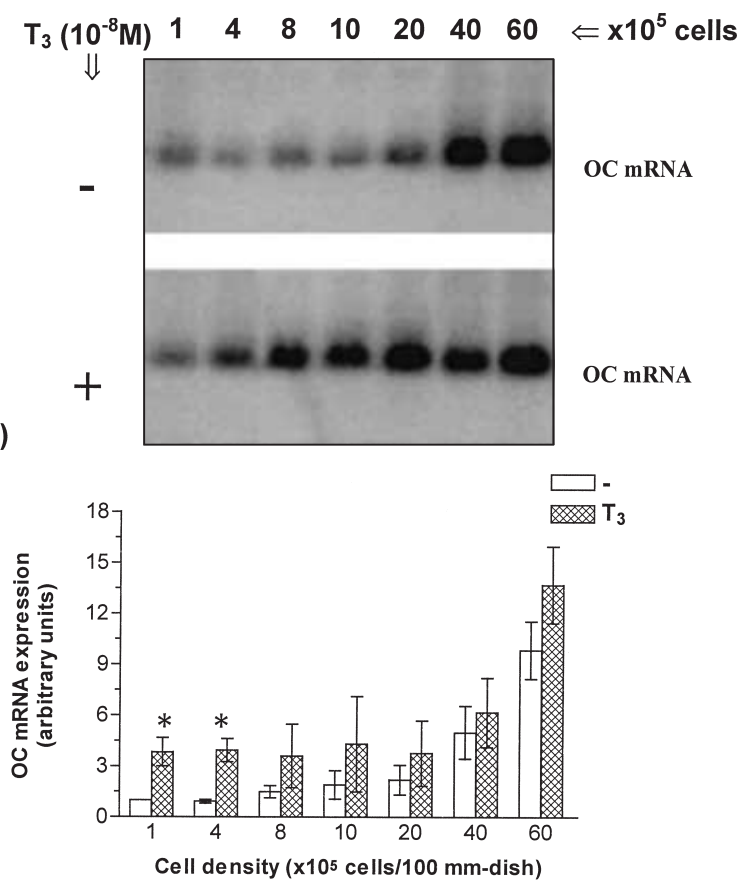

(C)

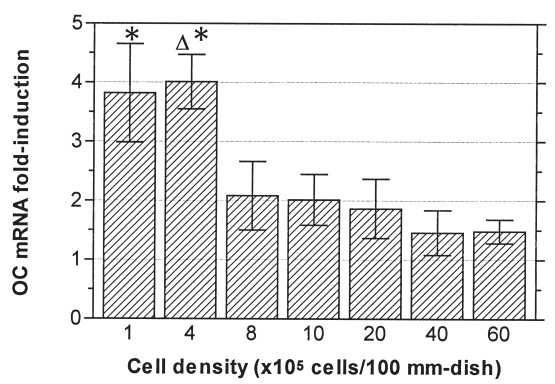

Figure 3 Effect of cell density on $\mathrm{T}_{3}$ induction of OC mRNA expression. ROS $17 / 2 \cdot 8$ cells were plated in varying cell densities and treated with $10^{-8} \mathrm{M} \mathrm{T}_{3}$ for $24 \mathrm{~h}$. (A) A Northern blot of $20 \mu \mathrm{g}$ total RNA/lane hybridized with OC ${ }^{32}$ P-labeled cDNA probe is shown. (B) Densitometric analysis of $\mathrm{T}_{3}$ - and cell density-induced changes in OC mRNA expression. Data are given as arbitrary units (OC/18S rRNA) and as means \pm S.E.M. $(n=3-4)$. ${ }^{*} P<0 \cdot 05$ in relation to control $(-)$ cells in each cell density. (C) Fold-induction of OC expression by $\mathrm{T}_{3} ;{ }^{*} P<0.05$ vs $40-60 \times 10^{5}$ cells $/ 100 \mathrm{~mm}$ dish and $\Delta P<0.05$ vs $8-20 \times 10^{5}$ cells $/ 100 \mathrm{~mm}$ dish. $P$ value by ANOVA is $\leqslant 0.002$ in (B) and (C).

We determined the effects of $\mathrm{T}_{3}$ on the rate of $\mathrm{OC}$ gene transcription by performing nuclear run-off assay. Transcriptionally active nuclei were isolated from ROS $17 / 2 \cdot 8$ cells maintained for $24 \mathrm{~h}$ in the absence (control cells, - ) or presence of $10^{-8} \mathrm{M} \mathrm{T}_{3}$. The nascent transcripts were hybridized to filter-bound OC cDNA. $\mathrm{T}_{3}$ treatment for $24 \mathrm{~h}$ stimulated the rate of OC transcription 1.7-fold compared with control cells $(P<0 \cdot 05, n=4)$ (Fig. 5).

Although the magnitude of transcriptional stimulation by $\mathrm{T}_{3}$ was modest, a reporter construct containing $1.8 \mathrm{~kb}$ 
(A)

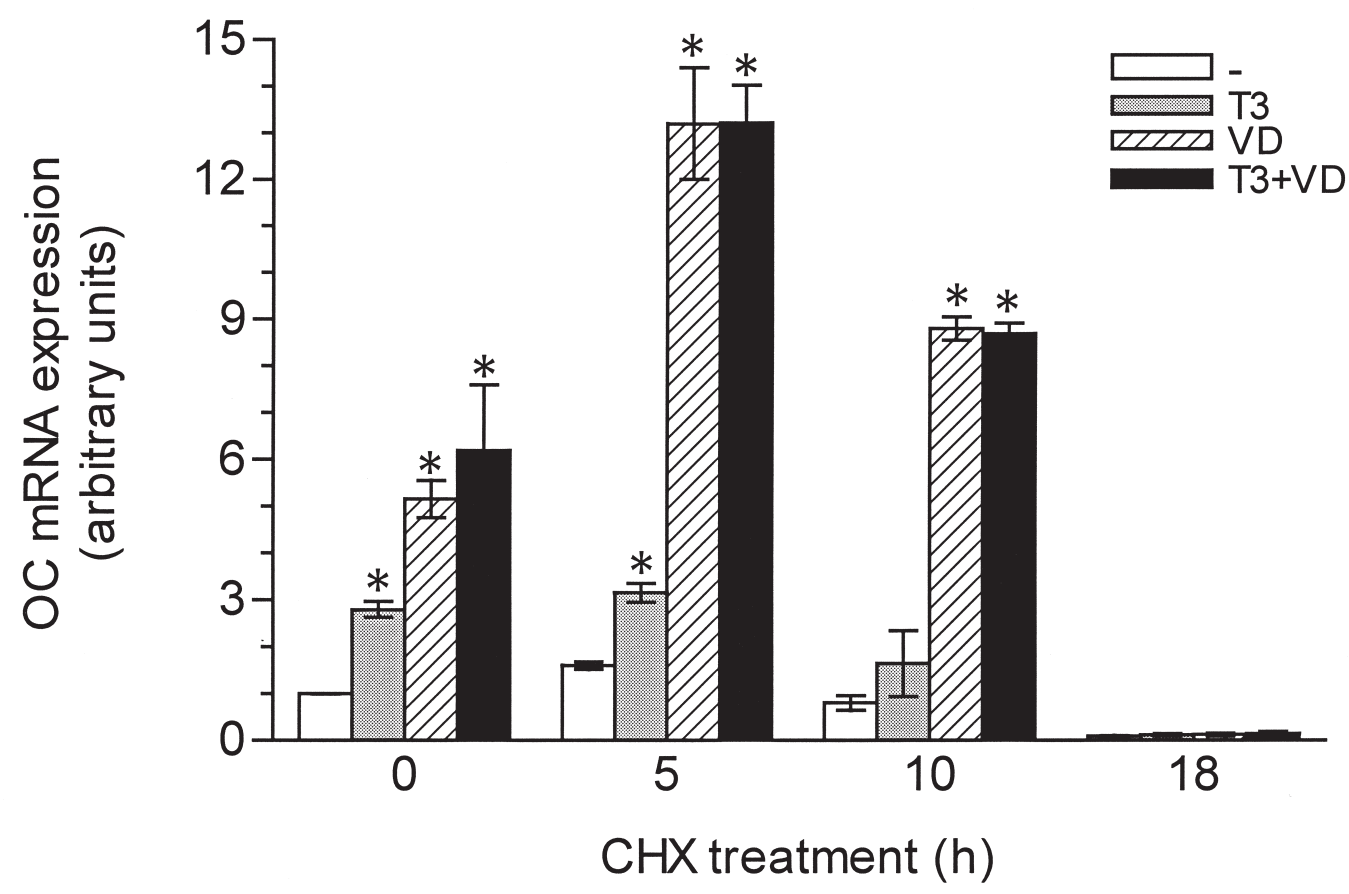

(B)

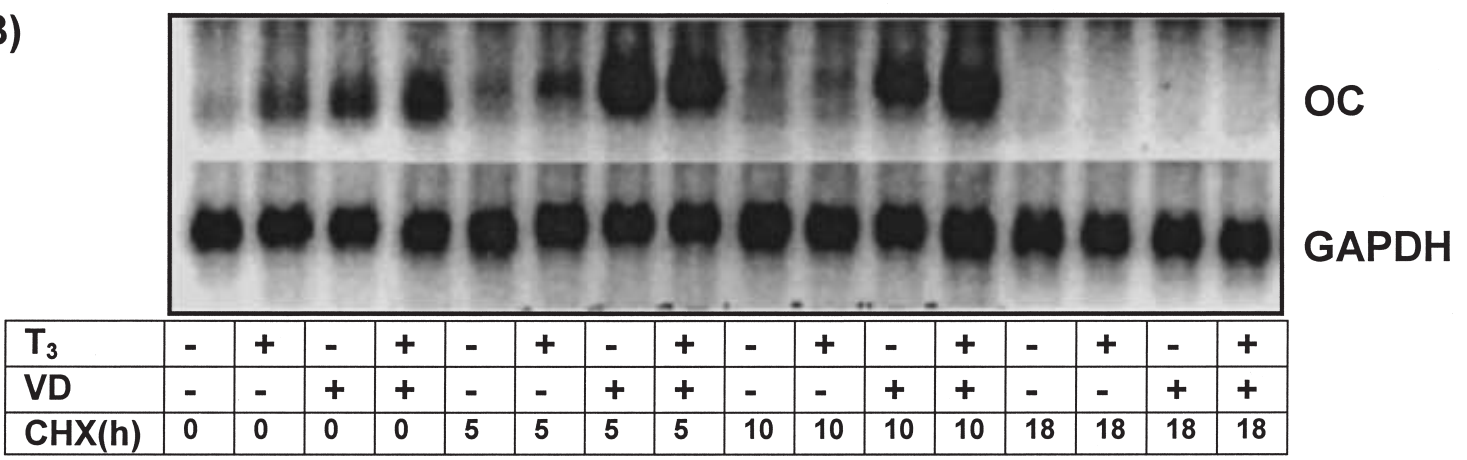

Figure 4 Effect of $\mathrm{T}_{3}$ and $1,25 \mathrm{D}_{3}$ treatment on $\mathrm{OC}$ mRNA expression in the presence of $\mathrm{CHX}$. Cells were cultured in SF medium for $24 \mathrm{~h}$ before $\mathrm{CHX}(10 \mu \mathrm{g} / \mathrm{ml})$ plus $\mathrm{T}_{3}$ and/or $1,25 \mathrm{D}_{3}(\mathrm{VD})$ (both at $10^{-8} \mathrm{M}$ ) treatment for 5,10 or $18 \mathrm{~h}$. Cells were then washed twice with PBS and returned to hormone treatment for a total of $24 \mathrm{~h}$. RNA ( $30 \mu \mathrm{g}$ total RNA/lane) from ROS $17 / 2 \cdot 8$ cells was analyzed by Northern blot using ${ }^{32}$ P-labeled cDNA probes specific for OC and GAPDH. GAPDH mRNA expression was used for normalization. (A) Densitometric analysis of mRNA expression is shown as arbitrary units $(\mathrm{OC} / \mathrm{GAPDH})$, means \pm S.E.M.; ${ }^{*} P<0 \cdot 05$ vs control (open bars). (B) Northern blot shows the expression of OC and GAPDH mRNAs.

of the rat $\mathrm{OC}$ gene $(\mathrm{rOC}) 5^{\prime}$-flanking region, POC $_{2 \cdot 0}$ CAT, was transfected into ROS $17 / 2 \cdot 8$ cells to determine the $\mathrm{T}_{3}$ response (data not shown). $\mathrm{T}_{3}$ treatment did not stimulate the OC promoter, while $1,25 \mathrm{D}_{3}$ treatment resulted in a $6 \cdot 6$-fold $(P<0 \cdot 001)$ induction of CAT expression. No further induction was observed when cells were treated with $\mathrm{T}_{3}+1,25 \mathrm{D}_{3}(6 \cdot 8$-fold, $P<0 \cdot 001$ vs con- trol). Due to the similarity in response elements for TR and VDR (Schrader et al. 1994a), we also tested the possibility that $\mathrm{T}_{3}$ could transactivate the $\mathrm{OC}$ promoter through the previously described rOC VDRE. $1,25 \mathrm{D}_{3}$ treatment resulted in a $2 \cdot 1$-fold $(P<0 \cdot 05)$ increase of the rOCVDRE-LUC reporter construct activity, but $\mathrm{T}_{3}$ had no effect, with or without $1,25 \mathrm{D}_{3}$ (data not shown). 
Table 1 OC mRNA half-life. Values are presented as means \pm S.E.M $(n=4)$

\begin{tabular}{|c|c|c|c|c|}
\hline & Slope $(\% / h)$ & $\mathbf{R}^{2}$ & $P$ & Half-life (h) \\
\hline SF & $-7 \cdot 8 \pm 0 \cdot 3$ & 0.98 & $0 \cdot 001$ & $6 \cdot 4 \pm 0 \cdot 2$ \\
\hline $\mathrm{T}_{3}$ & $-4 \cdot 8 \pm 0 \cdot 3$ & 0.93 & 0.007 & $10 \cdot 9 \pm 0 \cdot 6^{*}$ \\
\hline $1,25 D_{3}$ & $-3 \cdot 7 \pm 0 \cdot 1$ & 0.95 & 0.005 & $13 \cdot 5 \pm 0 \cdot 4^{*}$ \\
\hline $\mathrm{T}_{3}+1,25 \mathrm{D}_{3}$ & $-4 \cdot 2 \pm 0 \cdot 5$ & 0.90 & $0 \cdot 013$ & $11 \cdot 9 \pm 1 \cdot 3^{*}$ \\
\hline
\end{tabular}

${ }^{*} P<0.01$ compared with SF.

(A)

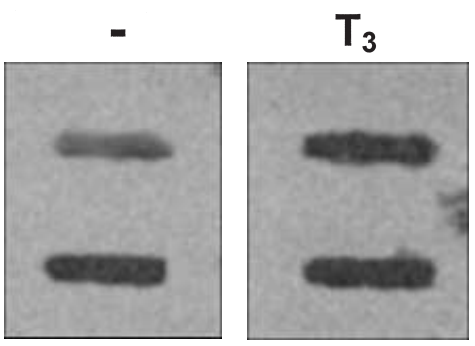

(B)

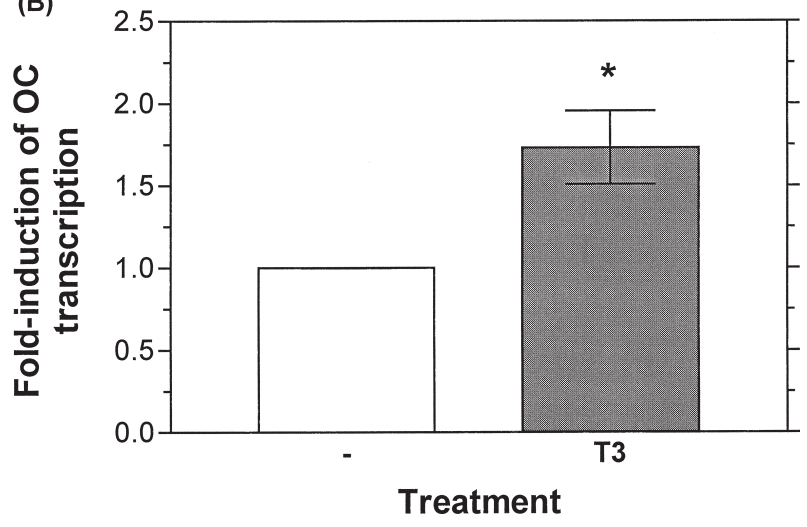

Figure 5 Run-off transcription analysis of OC in ROS 17/2.8 cells treated with $\mathrm{T}_{3}$. (A) ${ }^{32} \mathrm{P}$ run-off transcripts from nuclei of control $(-)$ and $\mathrm{T}_{3}$-treated cells at $24 \mathrm{~h}$ were hybridized to $20 \mu \mathrm{g}$ denatured double-stranded OC and GAPDH cDNAs for $72 \mathrm{~h}$. (B) Densitometric analysis is shown as fold-induction in relation to control (SF) and as means \pm S.E.M. $(n=4),{ }^{*} P=0.02$ by Student's t-test (unpaired).

\section{Discussion}

A significant finding of the present investigation was that $\mathrm{T}_{3}$ significantly increased OC mRNA half-life. The $\mathrm{T}_{3}$-dependent control of mRNA stability is an important mechanism of thyroid hormone regulation of gene expression. Genes such as cytochrome P450 in HepG2 cells (Peng \& Coon 1998), $\beta 3$-adrenoceptor in adipocytes (el Hadri et al. 1996) and apoliprotein-AI in Hep G2 cells (Vandenbrouck et al. 1995) are all up-regulated by $\mathrm{T}_{3}$, predominantly by an increase in the mRNA half-life (100\%, 36\% and 300\% respectively), while transcriptional effects of $\mathrm{T}_{3}$ were not observed by run-off assay.
We additionally determined whether the effects of thyroid hormone on $\mathrm{OC}$ gene expression required new protein synthesis. Since $1,25 \mathrm{D}_{3}$ is known to have direct and indirect effects on OC gene expression (Stein et al. 1996), we also used $1,25 \mathrm{D}_{3}$ and $1,25 \mathrm{D}_{3}+\mathrm{T}_{3}$ to compare to the effects of $\mathrm{T}_{3}$ alone. $\mathrm{T}_{3}$ up-regulated OC mRNA expression after $5 \mathrm{~h}$ of CHX treatment but not after $10 \mathrm{~h}$, a time at which the effects of $1,25 \mathrm{D}_{3}$ on OC mRNA were still detectable. This is an indication that $\mathrm{T}_{3}$ stimulation of OC mRNA is mediated through short half-life proteins, such as TR and potentially RNA binding proteins. It is interesting that in $\mathrm{GH}_{1}$ cells, exposure to $T_{3}$ induces down-regulation of TR (Raaka \& Samuels 1981) by mechanisms that involve ubiquitination and selective proteolysis by the proteasomes (Dace et al. 2000). On the other hand, exposure to $1,25 \mathrm{D}_{3}$ stabilizes VDR in CHXtreated ROS $17 / 2 \cdot 8$ cells, and the corresponding VDR half-life increases from $2 \mathrm{~h}$ to $15 \mathrm{~h}$ (van den Bemd et al. 1996). Although receptor availability is a reasonable explanation for our findings, it is possible that other mechanisms may be involved. In GC cells, for example, $\mathrm{T}_{3}$ stimulates the type $15^{\prime}$-deiodinase (D1) gene by mechanisms not sensitive to $\mathrm{CHX}$, whereas the $\mathrm{T}_{3}$ effects on $\mathrm{GH}$ mRNA synthesis are CHX sensitive (Maia et al. 1995).

$\mathrm{T}_{3}$ regulates genes by inducing transcription alone (e.g. SERCA1 (Thelen et al. 1994); D1 and GH (Raaka \& Samuels 1981); collagenase-3 and gelatinase B (Pereira et al. 1999)) or in combination with mRNA stabilization (e.g. malic enzyme (Back et al. 1986) and uncoupling protein-1 (UCP-1) (Bianco et al. 1988, Rehnmark et al. 1992)). In addition to stabilizing OC mRNA, $T_{3}$ treatment enhanced the rate of $\mathrm{OC}$ transcription, $\sim 1 \cdot 7$-fold, as determined by nuclear run-off assay. $\mathrm{T}_{3}$ induction of $\sim 1.8 \mathrm{~kb}$ of the $5^{\prime}$-flanking region of the OC gene was tested in ROS $17 / 2 \cdot 8$ cells (Demay et al. 1989). This sequence is sufficient (i) to provide basal promoter activity (Towler et al. 1994), (ii) to direct osteoblast-specific expression and (iii) to confer full $1,25 \mathrm{D}_{3}$-mediated transactivation of the OC gene (Demay et al. 1989). Nevertheless, $T_{3}$ treatment did not induce CAT activity, while $1,25 \mathrm{D}_{3}$, as expected, stimulated the promoter activity approximately $6 \cdot 6$-fold under the same conditions. $\mathrm{T}_{3}$ also did not induce the $53 \mathrm{bp}$ sequence containing the rOC VDRE, a critical sequence for $1,25 \mathrm{D}_{3}$ transactivation (Sneddon et al. 1997). The element conferring $\mathrm{T}_{3}$ induction may be located outside of the $1.8 \mathrm{~kb} 5^{\prime}$-flanking region studied, or the element may be too weak to map in a transient transfection system. VDR interacts in solution with $\mathrm{TR}$ and $\mathrm{T}_{3}$ treatment can enhance the response compared with $1,25 \mathrm{D}_{3}$ alone (Schrader et al. 1994b). TR has been shown to repress $1,25 \mathrm{D}_{3}$-mediated transactivation (Raval-Pandya et al. 1998), and VDR can antogonize $T_{3}$ induction (Yen et al. 1996), although these effects were not observed in our system.

Multiple levels of gene regulation by hormones have been shown in a number of systems, and the level of 
regulation can vary depending on the extent of cell differentiation. For example, $1,25 \mathrm{D}_{3}$ regulates $\mathrm{OC}$ expression in ROS $17 / 2.8$ cells primarily by increasing the mRNA half-life, but stimulates transcription in cells that express a less mature osteoblast phenotype (Shalhoub et al. 1998). Nuclear hormone receptor co-activators and corepressors expressed during development may modulate some of these effects.

$\mathrm{T}_{3}$ induction of $\mathrm{OC}$ gene expression was dependent on cell density. Basal OC gene expression was increased in conditions of high cell density, whereas OC mRNA induction by $\mathrm{T}_{3}$ was decreased. A previous study showed that an increase in $\operatorname{ROS} 17 / 2 \cdot 8$ cell density inhibits expression of proliferation-specific genes and increases expression of mature bone-related genes, including OC (van den Ent et al. 1993). A similar effect of cell density on $\mathrm{T}_{3}$ stimulation of gene expression was found for the $\mathrm{Na}$-K-ATPase $\alpha 3$ gene. $\mathrm{T}_{3}$ induction was present at $4 \times 10^{6}$ cardiac myocytes/plate but not when twice as many were plated (Chin et al. 1998). In a related study, cell confluence changed the response of $\mathrm{OC}$ to $\mathrm{T}_{3}$ in $\mathrm{ROS}$ $17 / 2 \cdot 8$ cells; however, maximal induction by $\mathrm{T}_{3}$ was seen at both low and high cell densities (Williams et al. 1995). In our hands, the maximal induction of OC mRNA expression by $\mathrm{T}_{3}$ was achieved in cells that were approximately $20-30 \%$ confluent. In $100 \%$ confluent cells the $\mathrm{T}_{3}$-mediated induction of OC expression decreased $\sim 50 \%$ and was abolished in overly confluent cells. In several aspects, this reciprocal regulatory relationship is analogous to the proliferation/differentiation transition stage observed during development of the bone cell phenotype in normal diploid osteoblasts.

In conclusion, in ROS $17 / 2 \cdot 8$ cells, $T_{3}$ does not interact with $1,25 \mathrm{D}_{3}$ to regulate the $\mathrm{OC}$ gene but up-regulates the OC mRNA expression in a dose-, time- and cell confluence-dependent fashion and requires ongoing protein synthesis to sustain the increase in OC expression. Moreover, our results indicate that $\mathrm{T}_{3}$ regulates $\mathrm{OC}$ expression at the transcriptional and post-transcriptional levels. The greater $\mathrm{T}_{3}$ induction of OC expression in ROS $17 / 2 \cdot 8$ cells at low cell density is consistent with thyroid hormone action during bone development.

\section{Acknowledgements}

This work was supported by research funds from the Department of Veteran Affairs, National Institutes of Health Grant DK 43714 (G A B), and a scholarship from Fundacão Coordenacão de Aperfeicoamento de Pessoal de Nível Superior, Brazil (C H G).

\section{References}

Allain TJ \& McGregor AM 1993 Thyroid hormones and bone. Journal of Endocrinology 139 9-18.
Allain TJ, Yen PM, Flanagan AM \& McGregor AM 1996 The isoform-specific expression of the triiodothyronine receptor in osteoblasts and osteoclasts. European Journal of Clinical Investigation 26 418-425.

Aronow M, Gerstenfeld L, Owen T, Tassinari M, Stein G \& Lian J 1990 Factors that promote progressive development of the osteoblast phenotype in cultured fetal rat calvaria cells. Journal of Cell Physiology 143213 -221.

Ausubel FM, Brent R, Kingston RE, Moore DD, Seidman JG, Smith JA \& Struhl K 1997 Current Protocols in Molecular Biology. New York, NY: John Wiley \& Sons, Inc.

Back DW, Wilson SB, Morris SM Jr \& Goodridge AG 1986 Hormonal regulation of lipogenic enzymes in chick embryo hepatocytes in culture. Thyroid hormone and glucagon regulate malic enzyme mRNA level at post-transcriptional steps. Journal of Biological Chemistry 261 12555-12561.

van den Bemd GC, Pols HA, Birkenhager JC \& van Leeuwen JP 1996 Conformational change and enhanced stabilization of the vitamin $\mathrm{D}$ receptor by the 1,25 -dihydroxyvitamin $\mathrm{D}_{3}$ analog KH1060. PNAS 93 10685-10690.

Bianco AC, Sheng XY \& Silva JE 1988 Triiodothyronine amplifies norepinephrine stimulation of uncoupling protein gene transcription by a mechanism not requiring protein synthesis. Journal of Biological Chemistry 263 18168-18175.

Boskey AL, Gadaleta S, Gundberg C, Doty SB, Ducy P \& Karsenty G 1998 Fourier transform infrared microspectroscopic analysis of bones of osteocalcin-deficient mice provides insight into the function of osteocalcin. Bone 23 187-196.

Chin S, Apriloetti J \& Gick G 1998 Characterization of a negative thyroid hormone response element in the rat sodium, potassium-adenosine triphosphatase alpha3 gene promoter. Endocrinology 139 3423-3431.

Dace A, Zhao L, Park KS, Furuno T, Takamura N, Nakanishi M, West BL, Hanover JA \& Cheng S-Y 2000 Hormone binding induces rapid proteasome-mediated degradation of thyroid hormone receptors. PNAS $978985-8990$.

Demay MB, Roth DA \& Kronenberg HM 1989 Regions of the rat osteocalcin gene which mediate the effect of 1,25-dihydroxyvitamin $\mathrm{D}_{3}$ on gene transcription. Journal of Biological Chemisty 264 2279-2282.

Diamond T, Nery L \& Hales I 1991 A therapeutic dilemma: suppressive doses of thyroxine significantly reduce bone mineral measurements in both premenopausal and postmenopausal women with thyroid carcinoma. Journal of Clinical Endocrinology and Metabolism 72 1184-1188.

Ducy P, Desbois C, Boyce B, Pinero G, Story B, Dunstan C, Smith K, Bonadio J, Goldstein S, Gundberg C, Bradley A \& Karsenty G 1996 Increased bone formation in osteocalcin-deficient mice. Nature $382448-452$.

van den Ent FM, van Wijnen AJ, Last TJ, Bortell R, Stein JL, Lian JB \& Stein GS 1993 Concerted control of multiple histone promoter factors during cell density inhibition of proliferation in osteosarcoma cells: reciprocal regulation of cell cycle-controlled and bone-related genes. Cancer Research 53 2399-2409.

Fraichard A, Chassande O, Plateroti M, Roux JP, Trouillas J, Dehay C, Legrand C, Rousset B \& Samarut J 1997 The T3R alpha gene encoding a thyroid hormone receptor is essential for post-natal development and thyroid hormone production. EMBO Journal 16 4412-4420.

Gauthier K, Chassande O, Plateroti M, Roux JP, Legrand C, Pain B, Rousset B, Weiss R, Trouillas J \& Samarut J 1999 Different functions for the thyroid hormone receptors TRalpha and TRbeta in the control of thyroid hormone production and post-natal development. EMBO Journal 18 623-631.

Glowacki J \& Lian JB 1987 Impaired recruitment and differentiation of osteoclast progenitors by osteocalcin-deplete bone implants. Cell Differentiation $21247-254$. 
Göthe S, Wang Z, Ng L, Kindblom JM, Barros AC, Ohlsson C, Vennström B \& Forrest D 1999 Mice devoid of all known thyroid hormone receptors are viable but exhibit disorders of the pituitarythyroid axis, growth, and bone maturation. Genes and Development 15 1329-1341.

Gouveia CH, Jorgetti W \& Bianco AC 1997 Effects of thyroid hormone administration and estrogen deficiency on bone mass of female rats. Journal of Bone and Mineral Research 12 2098-2107.

el Hadri K, Pairault J \& Feve B 1996 Triiodothyronine regulates beta 3 -adrenoceptor expression in 3T3-F442A differentiating adipocytes. European Journal of Biochemistry 239 519-525.

Kojima N, Sakata S, Nakamura S, Nagai K, Takuno H, Ogawa T, Matsui I, Sarui H \& Miura K 1992 Serum concentrations of osteocalcin in patients with hyperthyroidism, hypothyroidism and subacute thyroiditis. Journal of Endocrinological Investigation $\mathbf{1 5}$ 491-496.

Krolner B, Jorgensen JV \& Nielsen SP 1983 Spinal bone mineral content in myxoedema and thyrotoxicosis. Effects of thyroid hormone(s) and antithyroid treatment. Clinical Endocrinology 18 439-446.

Kung AW \& Ng F 1994 A rat model of thyroid hormone-induced bone loss: effect of antiresorptive agents on regional bone density and osteocalcin gene expression. Thyroid 4 93-98.

LeBron BA, Pekary AF, Mirell C, Hahn TJ \& Hershman JM 1989 Thyroid hormone $5^{\prime}$-deiodinase activity, nuclear binding, and effects on mitogenesis in UMR-106 osteoblastic osteosarcoma cells. Journal of Bone and Mineral Research 4 173-178.

Lerger J, Ruiz JC, Guibourdenche J, Kindermans C, Garabedian M \& Czernichow P 1997 Bone mineral density and metabolism in children with congenital hypothyroidism after prolonged L-thyroxine therapy. Acta Paediatrica 86 704-710.

McSheehy PM \& Chambers TJ 1987 1,25-Dihydroxyvitamin D3 stimulates rat osteoblastic cells to release a soluble factor that increases osteoclastic bone resorption. Journal of Clinical Investigation $198780425-429$.

Maia AL, Kieffer JD, Harney JW \& Larsen PR 1995 Effect of $3,5,3^{\prime}$-triiodothyronine $\left(T_{3}\right)$ administration on diol gene expression and $\mathrm{T}_{3}$ metabolism in normal and type 1 deiodinase-deficient mice. Endocrinology 136 4842-4849.

Mosavin R \& Mellon WS 1996 Posttranscriptional regulation of osteocalcin mRNA in clonal osteoblast cells by 1,25 dihydroxyvitamin $\mathrm{D}_{3}$. Archives of Biochemistry and Biophysics 332 142-152.

Mosekilde L \& Melsen F 1978 A tetracycline-based histomorphometric evaluation of bone resorption and bone turnover in hyperthyroidism and hyperparathyroidism. Acta Medica Scandinavica 204 97-102.

Pan LC \& Price PA 1985 The propeptide of rat bone gammacarboxyglutamic acid protein shares homology with other vitamin K-dependent protein precursors. PNAS 18 6109-6113.

Peng HM \& Coon MJ 1998 Regulation of rabbit cytochrome P450 2E1 expression in HepG2 cells by insulin and thyroid hormone. Molecular Pharmacology 54 740-747.

Pereira RC, Jorgetti V \& Canalis E 1999 Triiodothyronine induces collagenase-3 and gelatinase B expression in murine osteoblasts. Journal of Physiology 277 E496-E504.

Raaka BM \& Samuels HH 1981 Regulation of thyroid hormone nuclear receptor levels in GH1 cells by 3,5,3'-triiodo-L-thyronine. Use of dense amino acid labeling to determine the influence of hormone on the receptor half-life and the rate of appearance of newly synthesized receptor. Journal of Biological Chemistry 256 6883-6889.

Raval-Pandya M, Freedman LP, Li H \& Christakos S 1998 Thyroid hormone receptor does not heterodimerize with the vitamin D receptor but represses vitamin D receptor-mediated transactivation. Molecular Endocrinology 12 1367-1379.
Rehnmark S, Bianco AC, Kieffer JD \& Silva JE 1992 Transcriptional and posttranscriptional mechanisms in uncoupling protein mRNA response to cold. American Journal of Physiology 262 E58-E67.

Rizzoli I, Poser J \& Burgi U 1986 Nuclear thyroid hormone receptors in cultured bone cells. Metabolism 35 71-74.

Ross DS \& Graichen RJ 1991 Increased rat femur osteocalcin mRNA concentrations following in vivo administration of thyroid hormone. Journal of Endocrinological Investigation 14 763-766.

Sato K, Han DC, Fujii Y, Tsushirna T \& Shizurne K 1987 Thyroid hormone stimulates alkaline phosphatase activity in cultured rat osteoblastic cells (ROS 17/2.8) through 3,5,3'-triiodo-L-thyronine nuclear receptors. Endocrinology 120 1873-1881.

Schrader M, Muller KM, Nayeri S, Kahlen JP \& Carlberg C 1994a Vitamin $\mathrm{D}_{3}$-thyroid hormone receptor heterodimer polarity directs ligand sensitivity of transactivation. Nature 370 382-386.

Schrader M, Muller KM \& Carlberg C $1994 b$ Specificity and flexibility of vitamin D signaling. Modulation of the activation of natural vitamin D response elements by thyroid hormone. Journal of Biological Chemistry 269 5501-5504.

Shalhoub V, Aslam F, Breen D, van Wijen A, Bortell R, Stein GS, Stein JL \& Lian JB 1998 Multiple levels of steroid hormonedependent control of osteocalcin during osteoblast differentiation: glucocorticoid regulation of basal and vitamin D stimulated gene expression. Journal of Cellular Biochemistry 69 154-168.

Sneddon WB, Bogado CE, Kiernan MS \& Demay MB 1997 DNA sequences downstream from the vitamin $\mathrm{D}$ response element of the rat osteocalcin gene are required for ligand-dependent transactivation. Molecular Endocrinology 11 210-217.

Stein GS, Lian JB, Stein JL, Wijnen AJV \& Montecino M 1996 Transcriptional control of osteoblast growth and differentiation. Physiology Reviews 76 593-629.

Thelen MH, Muller A, Zuidwijk MJ, van der Linden GC, Simonides WS \& van Hardeveld C 1994 Differential regulation of the expression of fast-type sarcoplasmic-reticulum $\mathrm{Ca}(2+)$-ATPase by thyroid hormone and insulin-like growth factor-I in the L6 muscle cell line. The Biochemical Journal 303 467-474.

Towler DA, Rutledge SJ \& Rodan GA 1994 Msx-2/Hox 8·1: a transcriptional regulator of the rat osteocalcin promoter. Molecular Endocrinology 8 1484-1493.

Vandenbrouck Y, Janvier B, Loriette C, Bereziat G \& MangeneyAndreani M 1995 Thyroid hormone modulates apolipoprotein-AI gene expression at the post-transcriptional level in Hep G2 cells. European Journal of Biochemistry 231 126-132.

Williams GR, Bland R \& Sheppard MC 1994 Characterization of thyroid hormone $\left(\mathrm{T}_{3}\right)$ receptors in three osteosarcoma cell lines of distinct osteoblast phenotype: interactions among $\mathrm{T}_{3}$, vitamin $\mathrm{D}_{3}$, and retinoid signaling. Endocrinology 135 2375-2385.

Williams GR, Bland R \& Sheppard MC 1995 Retinoids modify regulation of endogenous gene expression by vitamin $D_{3}$ and thyroid hormone in three osteosarcoma cell lines. Endocrinology 136 4304-4314.

Yen PM, Liu Y, Sugawara A \& Chin WW 1996 Vitamin D receptors repress basal transcription and exert dominant negative activity on triiodothyronine-mediated transcriptional activity. Journal of Biological Chemistry 271 10910-10916.

Yoneda M, Takatsuki K, Yamauchi K, Oiso Y, Kurokawa M, Kawakubo A, Izuchi K, Tanaka H, Kozawa O \& Miura Y 1988 Influence of thyroid function on serum bone Gla protein. Endocrinologia Japonica 35 121-129.

Received in final form 3 April 2001

Accepted 4 May 2001 